Program Studi Pendidikan Bahasa dan Sastra Indonesia FKIP Universitas Kuningan

\title{
MEKANISME PERTAHANAN EGO TOKOH SENTRAL SEBAGAI PENAGARUH BUDAYA PATRIARKI DALAM FILM KIM JI- YOUNG, BORN 1982
}

\author{
Lisa Nur Asmillah, Nensilianti, Syamsudduha \\ Program Pascasarjana Magister Pendidikan Bahasa, Universitas Negeri Makassar, \\ Makassar, Sulawesi Selatan Indonesia \\ lisa.nurasmillah@gmail.com
}

\begin{abstract}
ABSTRAK: Penelitian ini bertujuan untuk mendeskripsikan bentuk mekanisme pertahanan ego sebagai pengaruh dari budaya patriarki yang dialami oleh tokoh sentral perempuan, yakni Kim Ji-young. Jenis penelitian ini adalah penelitian deskriptif-kualitatif dengan menggunakan pendekatan psikologi sastra berdasarkan teori Sigmund Freud mengenai mekanisme pertahanan ego. Sumber data yang digunakan berasal dari dialog film Kim Ji-young, Born 1982 dengan bentuk data tulisan berupa kata, frasa, klausa, atau kalimat. Hasil penelitian ini menunjukkan ada 8 bentuk mekanisme pertahanan ego yang terdiri atas 11 data. Bentuk mekanisme pertahanan ego yang paling sering digunakan adalah introjeksi sebanyak 4 data. Sementara untuk 7 bentuk lainnya yakni: (1) represi, (2) pengingkaran, (3) pengalihan, (4) formasi reaksi, (5) pembalikan, (6) agresi, (7) rasionalisasi, masing-masing terdiri atas 1 data.
\end{abstract}

KATA KUNCI: mekanisme pertahanan ego, patriarki, film ,

\section{CENTRAL FIGURE'S EGO DEFENSE MECHANISM AS A PATRIARCHIC CULTURAL INFLUENCE IN THE MOVIE OF KIM JI-YOUNG, BORN 1982}

\begin{abstract}
The purpose of this study is to describe the form of ego defense mechanism as the effects of patriarchal culture experienced by the female central figure, namely Kim Ji-young. This type of research is qualitative descriptive research used a literary pshychology approach based on Sigmund Freud's theory of ego defense mechanism. The data source used comes from the dialogue of Kim Ji-young, Born 1982's film with written data in the form or words, phrases, clauses, or sentences. The results of this study indicate that there are 8 forms of ego defense mechanism which most often used is introjection. Meanwhile, the other 7 forms are: (1) repression; (2) denial; (3) displacement; (4) reacrion-formation; (5) reversal; (6) aggression; and (7) rationalization, each consisting of 1 data.
\end{abstract}

Keywords: ego defense mechanism, patriarchy, movie.

\begin{tabular}{cccc}
\hline Diterima: & Direvisi: & Distujui: & Dipublikasi: \\
2021-07-05 & 2021-07-09 & 2021-09-01 & 2021-10-29 \\
& & & \\
Pustaka & Asmillah, L., Nensilianti, N., \& Syamsudduha, S. (2021). MEKANISME PERTAHANAN \\
& EGO TOKOH SENTRAL SEBAGAI PENAGARUH BUDAYA PATRIARKI DALAM \\
FILM KIM JI-YOUNG, BORN 1982. Fon: Jurnal Pendidikan Bahasa dan Sastra Indonesia, \\
17(2), 178-192. doi:https://doi.org/10.25134/fon.v17i2.4433 \\
\hline
\end{tabular}

\section{PENDAHULUAN}

Budaya menjadi salah satu pegangan hidup masyarakat. Pegangan hidup dalam sebuah budaya merupakan hal yang terus dijunjung tinggi sebab telah menjadi kebiasaan yang sulit untuk diubah. Dalam sebuah kebudayaan lahir adat istiadat yang berperan sebagai nilai-nilai norma yang mengatur tingkah laku bermasyarakat. Namun, tak sedikit kebudayaan dan praktik adat istiadat yang merugikan salah satu pihak, salah satunya, yaitu budaya patriarki.

Budaya patriarki merupakan bentuk ketidakadilan yang menempatkan perempuan sebagai pihak inferior dan lakulaki sebagai pihak superior. Dengan kata lain, budaya patriarki menjunjung nilainilai yang memosisikan laki-laki sebagai pihak yang mendominasi. Sistem otoritas ini dapat kita temui dalam berbagai aspek kehidupan, seperti lingkup sosial, 
Program Studi Pendidikan Bahasa dan Sastra Indonesia FKIP Universitas Kuningan

ekonomi, pendidikan, dan politik (Fakih, 2013).

Budaya patriarki berkembang dari adanya konsep maskulinitas dan femininitas yang pada akhirnya menentukan peran gender dalam tatanan kehidupan bermasyarakat. Hal ini didasarkan pada pendapat (Gamlin, 2020) yang menyatakan bahwa gender adalah sebuah pengkotak-kotakan yang berlaku secara umum dan dibentuk secara rasional melalui interaksi, tindakan, dan harapan individu maupun kelompok. Pembentukan peran gender tersebut didukung oleh struktur-struktur kehidupan, seperti keluarga, institusi pendidikan, atau bahkan ranah perekonomian negara.

Pada akhirnya, ketidakadilan gender ini merugikan kedua belah pihak, utamanya perempuan. Ketidakadilan gender dapat kita amati dari berbagai bentuk perwujudan ketimpangan. Fakih (2020) menyatakan ada lima manifestasi diskriminasi gender bagi pihak perempuan, yakni: marginalisasi, subordinasi, stereotip, kekerasan, dan beban kerja ganda. Marginalisasi berarti upaya yang membatasi hak dan jangkauan akses perempuan meliputi berbagai segi kehidupan, seperti pendidikan, pekerjaan, dan lain-lain. Subordinasi merupakan sikap yang memosisikan perempuan dalam kedudukan yang tidak penting. Stereotip adalah pelabelan yang cenderung merendahkan perempuan dibentuk tidak jauh dari adanya pengkategorisasian peran, fungsi, dan terhadap laki-laki dan perempuan yang dibentuk oleh masyarakat. Kekerasan merupakan bentuk serangan, baik secara verbal maupun non verbal yang mengakibatkan cedera fisik maupun psikologis seseorang. Beban ganda merupakan pemberian beban pengasuhan, dan pekerjaan rumah tangga bagi perempuan yang membantu perekonomian keluarga.Kelima manifestasi tersebut, baik secara langsung maupun tidak langsung, melanggengkan budaya patriarki.

Gambaran fenomena ketidakadilan gender sebagai wujud kasat mata dari budaya patriarki sering kita jumpai pada tayangan film. Dunia perfilman masa kini tidak hanya menjadi ajang bercerita, tetapi juga berperan dalam merepresentasi realitas sosial. Daya tarik film yang awalnya dikenal sebagai media hiburan, kini beralih menjadi sebuah singgungan terhadap isu-isu yang meresahkan dalam kehidupan sehari-hari (slice of life).

Salah satu film yang mengangkat isu realitas ketidakadilan gender sebagai manifestasi dari budaya patriarki adalah film Kim Ji-young, Born 1982. Melansir dari Detik Hot (2019), Kim Ji-young, Born 1982 merupakan sebuah film berdurasi 118 menit hasil adaptasi novel dengan judul yang sama. Novel tersebut sempat menjadi kontroversi, tetapi penjualannya tetap mampu mencapai 1 juta eksemplar. Begitu pula adaptasi filmnya yang telah ditonton sebanyak 1 juta penonton dalam 5 hari penayangan serta 3 juta penonton dalam kurun waktu 18 hari penayangan.

Berkisah tentang seorang perempuan bernama Kim Ji-young-perempuan berusia kisaran tiga puluh tahun-yang terpaksa harus melepaskan karier yang selama ini dibangunnya sebab memutuskan menikah dan memiliki anak. Ia akhirnya merasa kehilangan jati dirinya sendiri akibat tuntutan sebagai anak, istri, ibu, dan menantu yang sempurna dalam bingkai budaya patriarki Korea Selatan. Sejak kecil, Ji-young hidup dalam lingkungan dengan kepala keluarga yang menjunjung tinggi ideologi patriarki. Ayahnya begitu mengagungkan anak bungsu laki-lakinya. Tak hanya di lingkungan keluarga, segala aspek kehidupan di sekitar Kim Ji-young juga menggambarkan betapa patriarkisnya ideologi yang dianut oleh Korea Selatan. Pada akhirnya, beban, perlakuan-perlakuan seksis, misoginis, dan budaya patriarki 
Program Studi Pendidikan Bahasa dan Sastra Indonesia FKIP Universitas Kuningan

yang diterima oleh Kim Ji-young menggiringnya mengalami berbagai konflik batin.

Dalam memahami konflik batin yang dialami oleh tokoh sentral dalam suatu karya sastra, diperlukan pisau bedah yang tepat. Adapun pisau bedah yang tepat digunakan untuk menganalisis konflik batin tokoh, yakni psikologi sastra. Endraswara (2003) menyebutkan bahwa psikologi sastra adalah kajian sastra yang menilik hasil cipta karya sebagai aktivitas berkaitan dengan mentalitas. Tokoh utama dan pertama yang melahirkan gagasan mengenai psikologis manusia adalah Sigmund Freud. Gagasan yang dikemukakan oleh Freud dinamai dengan psikoanalisis.

Dalam konsepnya, Freud menganggap bahwa manusia memiliki energi psikis yang mendorong manusia untuk berperilaku dan sifatnya dinamis. Ada pun energi psikis yang dimaksud oleh Freud dalam kepribadian manusia ada tiga, yakni id, ego, dan superego. Menurut Setiaji (2019), prinsip id pada dasarnya menuntut pemerolehan dan pemenuhan kepuasan dan menghindari rasa sakit. Ketika id terpenuhi, timbul perasaan senang dan puas. Sebaliknya, ketika id tidak terpenuhi maka akan timbul ketegangan. Ringkasnya menurut Pieter \& Lubis (2016), id berisi energi psikis dan prinsip kepuasan.

Selanjutnya, ego merupakan kontinuitas dalam pencarian kesenangan (dalam id), namun tidak bersifat bebas sebab terikat oleh kepatutan untuk patuh pada realitas. Fase ini terjebak di antara id dan superego yang keduanya saling bertentangan. Ego berusaha untuk menyalurkan keinginan dan dorongan pada id, dan berusaha untuk memenuhi tata etika yang berlaku pada superego. Pembatasan keduanya pada akhirnya dibangun ego melalui penggambaran realitas. Oleh karena itu, jika id lahir dengan prinsip kepuasan, maka ego lahir dengan prinsip realita. Ringkasnya menurut Pieter \&
Lubis (2016), ego bertugas sebagai pengawas atau penanggung jawab realitas.

Terakhir, superego berisikan tatanan kepribadian yang mengandung unsur evaluatif (penilaian mengenai baik dan buruk). Komponen kepribadian ini merupakan aspek moral kepribadian sebab peran utamanya yakni menentukan perihal benar atau salah, pantas atau tidak pantas sehingga tindakannya dilakukan sesuai dengan tatanan moral dalam masyarakat. Ringkasnya menurut Pieter \& Lubis (2016), superego ialah kaidah-kaidah moral dan nilai-nilai sosial yang diserap dari lingkungan.

Menurut Boeree (2017) ketika terjadi konflik batin di antara kekuatan id dan superego untuk menguasai ego, maka sangat bisa dipahami kalau ego merasa terjepit dan terancam seolah-olah akan lenyap digilas kedua kekuatan tersebut. Perasaan terjepit ini disebut sebagai kecemasan (anxiety). Perasaan ini berfungsi sebagai tanda, bahwa ketika ia bertahan sambil tetap mempertimbangkan kelangsungan hidup, ia sebenarnya berada dalam bahaya.

Kecemasan yang menguasai, melahirkan pertahanan diri dari ego. Tanpa sadar, ego menghadang dorongan kecemasan tersebut menjadi wujud yang lebih dapat diterima dan tidak bersifat terlalu mengancam. Cara ini disebut sebagai mekanisme pertahanan diri (self defence mechanism). Davison dkk. (2014) mengemukakan delapan bentuk mekanisme pertahanan ego, yakni (1) represi, (2) pengingkaran, (3) proyeksi, (4) pengalihan, (5) formasi reaksi, (6) regresi,

(7) rasionalisasi, dan (8) sublimasi. Sementara itu, Boeree (2017) menambahkan satu lagi bentuk mekanisme pertahanan ego, yakni introjeksi. Pemaparan mengenai kesembilan bentuk mekanisme pertahanan diri tersebut diidentifikasikan dan diklasifikasikan pada tabel berikut ini. 
Program Studi Pendidikan Bahasa dan Sastra Indonesia FKIP Universitas Kuningan

\section{Tabel 1 Bentuk-bentuk Mekanisme Pertahanan Ego}

\begin{tabular}{|c|c|c|c|}
\hline No & $\begin{array}{c}\text { Bentuk } \\
\text { Mekanisme } \\
\text { Pertahan } \\
\text { Ego } \\
\end{array}$ & Definisi & Contoh \\
\hline 1. & $\begin{array}{l}\text { Represi } \\
\text { (Repression) }\end{array}$ & $\begin{array}{l}\text { Menghindari } \\
\text { impuls atau } \\
\text { kecemasan } \\
\text { serta perasaan } \\
\text { yang } \\
\text { menyakitkan } \\
\text { dan } \\
\text { mengancam } \\
\text { keluar dari } \\
\text { kesadaran. } \\
\text { Mekanisme } \\
\text { pertahanan ini } \\
\text { disebut juga } \\
\text { dengan } \\
\text { "melupakan } \\
\text { yang } \\
\text { bermotivasi". }\end{array}$ & $\begin{array}{l}\text { Pernyataan } \\
\text { "berhasil } \\
\text { selamat" oleh } \\
\text { seorang } \\
\text { alkoholik yang } \\
\text { tidak mengingat } \\
\text { upaya-upayanya } \\
\text { dalam } \\
\text { melakukan } \\
\text { tindakan bunuh } \\
\text { diri. }\end{array}$ \\
\hline 2. & $\begin{array}{l}\text { Pengingkaran } \\
\text { (Denial) }\end{array}$ & $\begin{array}{l}\text { Menjauhkan } \\
\text { kejadian- } \\
\text { kejadian } \\
\text { negatif dari } \\
\text { kesadaran } \\
\text { dengan cara } \\
\text { memblokir } \\
\text { peristiwa } \\
\text { yang terlalu } \\
\text { banyak } \\
\text { ditanggulangi } \\
\text { sendirian. }\end{array}$ & $\begin{array}{l}\text { Seorang anak } \\
\text { secara tidak } \\
\text { sadar menonton } \\
\text { adegan atau } \\
\text { iklan } \\
\text { mengerikan, } \\
\text { seperti senjata } \\
\text { tajam dan } \\
\text { darah, akan } \\
\text { refleks } \\
\text { memalingkan } \\
\text { wajahnya dari } \\
\text { arah televisi. }\end{array}$ \\
\hline 3. & $\begin{array}{l}\text { Proyeksi } \\
\text { (Projection) }\end{array}$ & $\begin{array}{l}\text { Mengatribusi } \\
\text { kesalahan } \\
\text { terhadap } \\
\text { orang lain } \\
\text { secara negatif } \\
\text { alih-alih } \\
\text { melakukan } \\
\text { penyadaran } \\
\text { terhadap diri } \\
\text { sendiri. }\end{array}$ & $\begin{array}{l}\text { Seorang remaja } \\
\text { memproyeksika } \\
\text { n penyebab } \\
\text { kenakalan yang } \\
\text { dilakukannya } \\
\text { kepada } \\
\text { orangtuanya, } \\
\text { bukan } \\
\text { mengintrospeksi } \\
\text { dirinya sendiri } \\
\text { sebagai } \\
\text { penyebab } \\
\text { kenakalannya } \\
\text { tersebut. }\end{array}$ \\
\hline 4. & $\begin{array}{l}\text { Pengalihan } \\
\text { (Displacemen } \\
t s)\end{array}$ & $\begin{array}{l}\text { Memilih } \\
\text { sasaran } \\
\text { pengganti } \\
\text { dari sasaran } \\
\text { sebenarnya } \\
\text { yang dapat } \\
\text { berupa benda } \\
\text { atau orang } \\
\text { lain. }\end{array}$ & $\begin{array}{l}\text { Seorang anak } \\
\text { yang membenci } \\
\text { ayahnya } \\
\text { mengarahkan } \\
\text { rasa bencinya } \\
\text { pada yang lain, } \\
\text { misal laki-laki } \\
\text { secara umum. }\end{array}$ \\
\hline 5. & $\begin{array}{l}\text { Formasi } \\
\text { Reaksi } \\
\text { (Reaction } \\
\text { Formation) }\end{array}$ & $\begin{array}{l}\text { Mengubah } \\
\text { suatu impuls } \\
\text { kecemasan } \\
\text { yang tidak } \\
\text { sesuai serta } \\
\text { tidak dapat } \\
\text { diterima } \\
\text { norma sosial } \\
\text { menjadi suatu } \\
\text { bentuk yang } \\
\text { lebih dapat } \\
\text { diterima }\end{array}$ & $\begin{array}{l}\text { Seseorang yang } \\
\text { memiliki impuls } \\
\text { agresif dalam } \\
\text { dirinya berubah } \\
\text { menjadi orang } \\
\text { yang ramah dan } \\
\text { sangat } \\
\text { bersahabat. }\end{array}$ \\
\hline
\end{tabular}

\begin{tabular}{|c|c|c|c|}
\hline 6. & $\begin{array}{l}\text { Pembalikan } \\
\text { (Reversal) }\end{array}$ & $\begin{array}{l}\text { Mereduksi } \\
\text { status ego } \\
\text { aktif menjadi } \\
\text { pasif dengan } \\
\text { mengubah } \\
\text { perasaan dan } \\
\text { impuls yang } \\
\text { menimbulkan } \\
\text { kecemasan } \\
\text { terhadap } \\
\text { orang lain } \\
\text { menjadi ke } \\
\text { arah sendiri. }\end{array}$ & $\begin{array}{l}\text { Seorang anak } \\
\text { yang memiliki } \\
\text { rasa benci } \\
\text { kepada ibunya } \\
\text { yang pilih } \\
\text { kasih, dibalik } \\
\text { menjad rasa } \\
\text { benci kepada } \\
\text { diri sendiri, atau } \\
\text { dibalik menjadi } \\
\text { rasa cinta yang } \\
\text { berlebih kepada } \\
\text { ibunya. }\end{array}$ \\
\hline 7. & $\begin{array}{l}\text { Regresi } \\
\text { (Regression) }\end{array}$ & $\begin{array}{l}\text { Membalikkan } \\
\text { pola perilaku } \\
\text { individu ke } \\
\text { tahap } \\
\text { pekembangan } \\
\text { level } \\
\text { sebelumnya } \\
\text { karena } \\
\text { kesulitan } \\
\text { untuk } \\
\text { memahami } \\
\text { respons yang } \\
\text { sesuai } \\
\text { terhadap } \\
\text { problema } \\
\text { yang } \\
\text { dihadapi. }\end{array}$ & $\begin{array}{l}\text { Seorang anak } \\
\text { kecil yang } \\
\text { memiliki adik } \\
\text { baru akan } \\
\text { menunjukkan } \\
\text { perilaku } \\
\text { menghisap } \\
\text { jempolnya atau } \\
\text { mengompol } \\
\text { mencari } \\
\text { perhatian orang } \\
\text { tuanya sebab } \\
\text { tak ingin bila } \\
\text { perhatian orang } \\
\text { tuanya } \\
\text { teralihkan } \\
\text { sepenuhnya } \\
\text { kepada adik } \\
\text { barunya. }\end{array}$ \\
\hline 8. & $\begin{array}{l}\text { Agresi } \\
\text { (Aggressive) }\end{array}$ & $\begin{array}{l}\text { Membalikkan } \\
\text { pola perilaku } \\
\text { secara } \\
\text { mundur oleh } \\
\text { orang dewasa } \\
\text { yang } \\
\text { mengalami } \\
\text { tekanan } \\
\text { psikologis } \\
\text { menuju pola } \\
\text { perilaku } \\
\text { primitif dan } \\
\text { kekanak- } \\
\text { kanakan yang } \\
\text { menjurus } \\
\text { pada } \\
\text { perusakan } \\
\text { dan } \\
\text { penyerangan. }\end{array}$ & $\begin{array}{l}\text { Seorang petani } \\
\text { yang ramah } \\
\text { mungkin akan } \\
\text { menjadi kejam } \\
\text { saat tahu tanah } \\
\text { pertaniannya } \\
\text { akan dijadikan } \\
\text { proyek } \\
\text { pembangunan. }\end{array}$ \\
\hline 9. & $\begin{array}{l}\text { Rasionalisasi } \\
\text { (Rasionalizati } \\
\text { on) }\end{array}$ & $\begin{array}{l}\text { Mengubah } \\
\text { penjelasan } \\
\text { negatif ke } \\
\text { dalam } \\
\text { penjelasan } \\
\text { positif } \\
\text { sehingga } \\
\text { penjelasan } \\
\text { atas } \\
\text { perilakunya } \\
\text { dapat } \\
\text { meninggalkan } \\
\text { kesan positif } \\
\text { dalam } \\
\text { masyarakat. }\end{array}$ & $\begin{array}{l}\text { Penjelasan } \\
\text { "membangun } \\
\text { karakter sang } \\
\text { anak" yang } \\
\text { dilontarkan oleh } \\
\text { orang tua yang } \\
\text { sedang } \\
\text { memarahi dan } \\
\text { meninggikan } \\
\text { suara pada } \\
\text { anaknya. }\end{array}$ \\
\hline 10. & $\begin{array}{l}\text { Sublimasi } \\
\text { (Sublimation) }\end{array}$ & $\begin{array}{l}\text { Mengalihkan } \\
\text { impuls } \\
\text { negatif } \\
\text { menjadi } \\
\text { impuls positif } \\
\text { dalam wujud }\end{array}$ & $\begin{array}{l}\text { Seseorang } \\
\text { sedang } \\
\text { merasakan } \\
\text { patah hati. } \\
\text { Untuk } \\
\text { menanggulangi }\end{array}$ \\
\hline
\end{tabular}


Program Studi Pendidikan Bahasa dan Sastra Indonesia FKIP Universitas Kuningan

\begin{tabular}{|c|c|c|c|}
\hline & & $\begin{array}{l}\text { aktivitas yang } \\
\text { berkaitan } \\
\text { dengan } \\
\text { kreativitas. }\end{array}$ & $\begin{array}{l}\text { emosi negatif } \\
\text { tersebut, ia } \\
\text { mulai menulis } \\
\text { puisi dan } \\
\text { membahasakan } \\
\text { rasa putus } \\
\text { asanya dalam } \\
\text { medium bahasa. }\end{array}$ \\
\hline 11. & $\begin{array}{l}\text { Introjeksi } \\
\text { (Introjection) }\end{array}$ & $\begin{array}{l}\text { Menggiring } \\
\text { adanya } \\
\text { kepribadian } \\
\text { orang lain ke } \\
\text { dalam diri } \\
\text { sebagai } \\
\text { bentuk } \\
\text { penyelesaian } \\
\text { masalah batin } \\
\text { yang } \\
\text { dianggap } \\
\text { mengganggu. }\end{array}$ & $\begin{array}{l}\text { Seorang anak } \\
\text { perempuan } \\
\text { yang kerap } \\
\text { tinggal } \\
\text { sendirian di } \\
\text { rumah karena } \\
\text { ditinggal } \\
\text { bekerja oleh } \\
\text { orangtuanya, } \\
\text { akan selalu } \\
\text { berlakon } \\
\text { sebagai seorang } \\
\text { ibu demi } \\
\text { menghilangkan } \\
\text { rasa takut dan } \\
\text { kesepiannya. } \\
\text { Anda dapat } \\
\text { memergokinya } \\
\text { berbicara pada } \\
\text { bonekanya } \\
\text { seolah-olah dia } \\
\text { adalah ibu dan } \\
\text { boneka itu } \\
\text { adalah bayinya. }\end{array}$ \\
\hline
\end{tabular}

Diolah dari: Boeree, (2017); Davison dkk. (2014); Yusuf (2004)

Penelitian mengenai mekanisme pertahanan ego juga pernah dilakukan oleh beberapa peneliti sebelumnya. Pertama, Afrikah \& Setyorini (2021). Penelitian tersebut mengangkat novel Si Anak Badai karya Tere Liye sebagai sumber datanya. Selain itu, penelitian tersebut juga menganalisis seluruh tokoh dalam novel, sementara penelitian yang dilakukan dipusatkan pada tokoh sentral dalam film. Kedua, Fatoni (2020) yang membahas mengenai struktur kepribadian dan mekanisme pertahanan ego tokoh dalam naskah drama Al-Wajhu Al-Muzlimli AlQamar Karya Najib Kailani. Penelitian oleh Fatoni menggunakan naskah drama sebagai sumber data, sedangkan penelitian yang dilakukan menggunakan film. Sementara itu, persamaannya adalah samasama menganalisis mengenai tokoh sentral dalam sumber data yang digunakan. Atas keterkaitan isu dan teori yang dipaparkan di atas, penelitian ini membahas mengenai bentuk mekanisme pertahanan ego tokoh sentral sebagai pengaruh dari budaya patriarki pada film Kim Ji-young, Born 1982.

\section{METODE}

Jenis penelitian ini adalah deskriptif kualitatif. Sumber data penelitian ini adalah dialog dalam film Kim Ji-young, Born 1982 karya Cho Nam-joo. Film tersebut diunduh dari aplikasi VIU yang merupakan aplikasi saluran legal dalam jaringan (daring). data yang berfokus pada kata, frasa, klausa, atau kalimat yang berkaitan dengan bentuk mekanisme pertahanan ego. Teknik pengumpulan data dilakukan dengan teknik simak dan teknik catat. Teknik simak dilakukan dengan memutar video dan menyimak adegan serta dialog yang terjadi pada film Kim Ji-young, Born 1982 yang telah diunduh melalui aplikasi VIU. Selanjutnya, teknik catat meliputi: (1) mencatat dialog dan deskripsi adegan untuk mendapatkan transkripsi naskah film; dan (2) melakukan pengecekan ketepatan transkripsi naskah dengan cara pemutaran kembali video film Kim Ji-young, Born 1982 yang dilakukan berulang demi memperoleh keakuratan data.

Ada pun teknik analisis data yang digunakan dalam penelitian ini, yakni: (1) identifikasi satuan (unit) pada transkripsi naskah yang dilakukan dengan mengidentifikasi kata, frasa, klausa, atau kalimat yang berhubungan dengan bentuk mekanisme pertahanan ego; (2) membuat koding yang dilakukan dengan memberikan kode pada setiap satuan data yang telah diidentifikasi. Pemberian kode dilakukan dengan contoh format (08/RPR/01.03.34) yang menandakan (Nomor Data/Singkatan Bentuk Mekanisme Pertahanan Ego/Jam.Menit.Detik); (3) kategorisasi data yang dilakukan dengan menyusun kategori data berdasarkan bentuk mekanisme pertahanan ego dan melabelisasi sesuai dengan istilah dalam bentuk-bentuk mekanisme pertahanan ego; 
Program Studi Pendidikan Bahasa dan Sastra Indonesia FKIP Universitas Kuningan

(4) menyusun hipotesis kerja yang dilakukan dengan melakukan analisis mendalam terhadap bentuk mekanisme pertahanan ego tokoh sentral sesuai dengan kajian psikoanalisis Sigmund Freud; dan (5) penarikan simpulan yang dilakukan berdasarkan hasil hipotesis kerja.

\section{HASIL DAN PEMBAHASAN}

Berdasarkan identifikasi data yang dilakukan, ditemukan 11 data mekanisme pertahanan ego dalam film Kim Ji-young, Born 1982 karya Cho Nam-joo. Data-data yang diperoleh akan dianalisis berdasarkan teori mekanisme pertahanan ego dengan kajian psikoanalisis Sigmund Freud. Dari 11 data yang ditemukan, diklasifikasi 8 bentuk mekanisme pertahanan ego yang dirinci: (1) represi sebanyak 1 data; (2) pengingkaran sebanyak 1 data; (3) pengalihan sebanyak 1 data; (4) formasi reaksi sebanyak 1 data; (5) pembalikan sebanyak 1 data; (6) agresi sebanyak 1 data; (7) rasionalisasi sebanyak 1 data; dan (8) interojeksi sebanyak 4 data. Untuk lebih rinci, perhatikan tabel berikut ini.

Tabel 1 Hasil Analisis Bentuk Mekanisme Pertahanan Ego

\begin{tabular}{|c|c|c|c|}
\hline No & $\begin{array}{l}\text { Mekanisme } \\
\text { Pertahanan Ego }\end{array}$ & Singkatan & $\begin{array}{c}\text { Jumlah } \\
\text { Data }\end{array}$ \\
\hline $\mathbf{1}$ & $\begin{array}{l}\text { Represi } \\
\text { (Repression) }\end{array}$ & RPR & 1 \\
\hline $\mathbf{2}$ & $\begin{array}{l}\text { Pengingkaran } \\
\text { (Denial) }\end{array}$ & PIK & 1 \\
\hline $\mathbf{3}$ & $\begin{array}{l}\text { Pengalihan } \\
\text { (Displacements) }\end{array}$ & PAH & 1 \\
\hline $\mathbf{4}$ & $\begin{array}{l}\text { Formasi Reaksi } \\
\text { (Reaction }\end{array}$ & FMRS & 1 \\
\hline $\mathbf{5}$ & $\begin{array}{l}\text { Formation) } \\
\text { Pembalikan } \\
\text { (Reversal) }\end{array}$ & PBK & 1 \\
\hline $\mathbf{6}$ & $\begin{array}{l}\text { Agresi } \\
\text { (Aggression) }\end{array}$ & AGR & 1 \\
\hline $\mathbf{7}$ & $\begin{array}{l}\text { Rasionalisasi } \\
\text { (Rasionalization) }\end{array}$ & RSN & 1 \\
\hline $\mathbf{8}$ & $\begin{array}{l}\text { Introjeksi } \\
\text { (Introjection) }\end{array}$ & ITJ & 4 \\
\hline & \begin{tabular}{l} 
Jumlah Data \\
\hline
\end{tabular} & $\mathbf{1 1}$ \\
\hline
\end{tabular}

\section{Bentuk Represi (Repression) Data (01/RPR/00.19.16)}

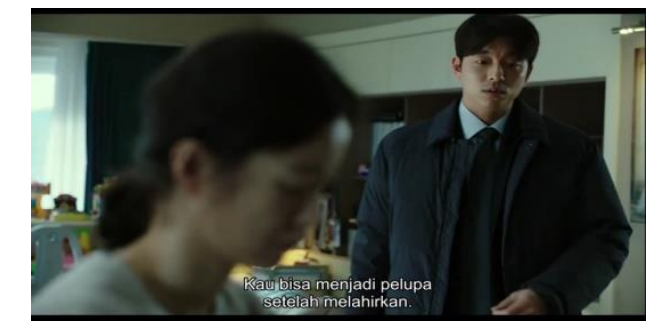

Gambar 1 Adegan Data (01/RPR/00.19.16)

\begin{tabular}{|c|c|c|}
\hline $\begin{array}{l}\text { Kim Ji- } \\
\text { young }\end{array}$ & & $\begin{array}{l}\text { "Mengapa kali ini ibu mertua } \\
\text { membungkuskan makanan unuk kita?" }\end{array}$ \\
\hline $\begin{array}{l}\text { Jung } \\
\text { Dae- } \\
\text { hyun }\end{array}$ & & $\begin{array}{l}\text { "Aku bilang aku tidak mau. Aku sudah merasa } \\
\text { cukup." }\end{array}$ \\
\hline $\begin{array}{l}\text { Kim Ji- } \\
\text { young }\end{array}$ & & $\begin{array}{l}\text { "Benarkah. Aku tidak ingat. Mengapa akhir- } \\
\text { akhir ini aku menjadi pelupa?" }\end{array}$ \\
\hline $\begin{array}{l}\text { Jung } \\
\text { Dae- } \\
\text { hyun }\end{array}$ & & $\begin{array}{l}\text { "Kau bisa menjadi pelupa setelah } \\
\text { melahirkan. Baru-baru ini seseorang dalam tim } \\
\text { kami melahirkan. Istrinya mengalami depresi } \\
\text { postpartum." }\end{array}$ \\
\hline
\end{tabular}

Data (01/RPR/00.19.16) yang

dicetak tebal di atas merupakan kalimat deklaratif dengan fokus pada frasa adjektiva menjadi pelupa dan frasa nomina depresi postpartum. Frasa adjektiva menjadi pelupa bermakna orang yang mengalami perubahan sering lupa. Sementara itu frasa nomina depresi pospartum adalah depresi yang dialami oleh perempuan pasca melahirkan. Depresi jenis ini dialami oleh ibu beberapa pekan setelah melahirkan dan dapat berlanjut hingga berbulan-bulan atau hingga bertahun-tahun jika tidak segera diatasi.

Melalui data di atas dapat diketahui kesulitan tokoh Kim Ji-young untuk beradaptasi dengan peran dan tanggung jawab barunya sebagai seorang ibu sehingga suaminya menganggapnya mengalami depresi pasca melahirkan. Depresi tersebut muncul sebagai akibat tekanan nilai-nilai moral bahwa seorang perempuan yang telah melahirkan harus secara langsung beradaptasi dengan peran dan tanggung jawabnya sebagai ibu baru. Selain itu, berdasarkan sifat feminin yang dikonstruksi oleh masyarakat, perempuan dewasa sudah sepantasnya memiliki naluri keibuan dalam dirinya.

Tekanan dan konflik batin yang dialami pada akhirnya membentuk mekanisme pertahanan ego berupa represi 
Program Studi Pendidikan Bahasa dan Sastra Indonesia

FKIP Universitas Kuningan

(repression). Represi merupakan upaya menghindari impuls atau kecemasan serta perasaan yang menyakitkan dan mengancam keluar dari kesadaran. Melalui jalan melupakan yang dilakukan secara bawah sadar, tokoh Kim Ji-young menghindari impuls atau kecemasan berupa perasaan takut akan kesulitannya mengemban peran dan tanggung jawab barunya sebagai ibu.

\section{Bentuk Pengingkaran (Denial)} Data (02/PIK/00.56.02)

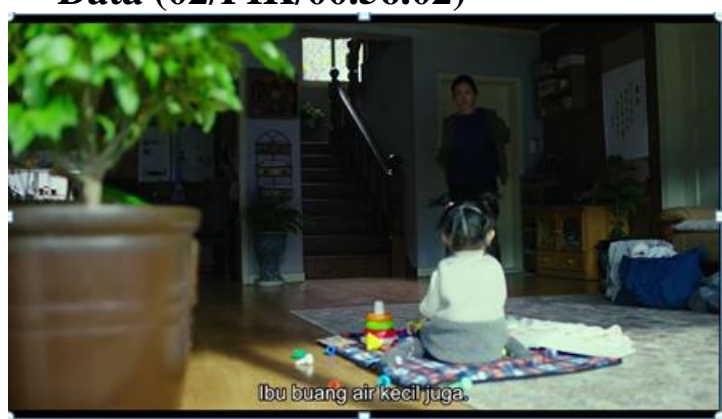
Jiyoung

"Ah-young, Ibu hampir selesai. Bersabarlah. Sudah! Ayo pergi ke rumah nenek." (Menggendong Ah-young sambil menenteng dua tas besar) "Tunggu. Ibu harus buang air kecil."

(Kim Ji-young masuk ke dalam bilik toilet. Ia bernia menggantung tas besar yang ditentengnya, tetapi gantungan di dinding terlalu tinggi. Akhirnya ia menyimpan tas tersebut di lantai saja. Saat ia hendak menurunkan celananya untuk buang air kecil, ia tertahan dan memeriksa sekeliling toilet cukup lama. Pada akhirnya, ia tidak jadi buang air kecil dalam toilet umum tersebut. Sesampainya di rumah ibunya, ia lekas menuju kamar kecil.)

Kim : "Akhirnya, Ibu buang air kecil juga." Ji- (Menuju Ah-young dan duduk bermain young bersamanya. Tak lama kemudian, ia tertidur.)

Data (02/PIK/00.56.02) yang dicetak tebal di atas, merupakan kalimat deklaratif dengan fokus pada adverbia akhirnya. Adverbia akhirnya pada data di atas menandakan suatu kelegaan, sebab ia dapat buang air kecil setelah menahannya di perjalanan dalam kereta. Melalui data tersebut dapat diketahui perasaan takut dan cemas Kim Ji-young menggunakan toilet umum karena banyaknya penemuan kasus kamera tersembunyi dalam bilik toilet.

Penemuan kamera tersembunyi dalam bilik toilet umum tersebut, tentu melanggar hukum yang berlaku mengenai hak dan privasi tubuh perempuan sebagai tindakan preventif objektivasi perempuan. Ketidaksesuaian norma hukum terhadap lingkungannya melahirkan perasaan cemas oleh Kim Ji-young. Rasa cemas tersebut pada akhirnya ditimbun hingga membentuk mekanisme pertahanan ego.

Bentuk mekanisme pertahanan ego yang dimunculkan adalah pengingkaran (denial). Pengingkaran (denial) adalah menjauhkan kejadian-kejadian negatif dari kesadaran dengan cara memblokir peristiwa yang terlalu banyak ditanggulangi sendirian. Tokoh Kim Jiyoung yang mengingat mengenai banyaknya penemuan kasus kamera tersembunyi dalam bilik toilet umum wanita membuatnya menahan keinginannya buang air kecil. Kasus kamera tersembunyi ini sangat merugikan perempuan. Selain pelaku menggunakannya untuk objek pemuasan kebutuhan seksual, pelaku juga mengeksploitasinya untuk diperdagangkan. Oleh karena itu, karena adanya trauma dan demi mencegah diri sebagai korban eksploitasi pornografi, Kim Ji-young melakukan pengingkaran dengan menghindari penggunaan toilet umum.

\section{Bentuk Pengalihan (Displacements) Data (03/PAH/00.18.58)}

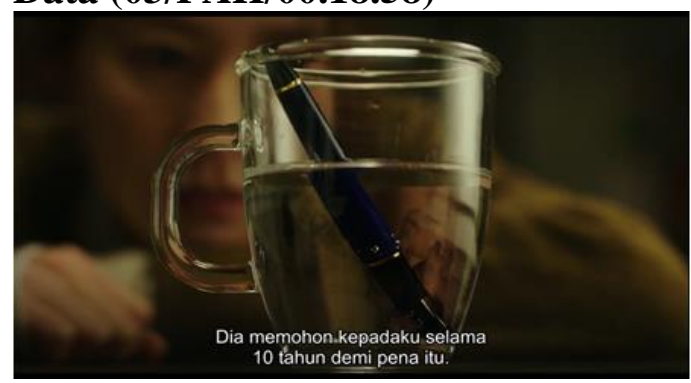

Gambar 3 Adegan Data (03/PAH/00.18.58)

Kim : "Bukankah ini pena yang satu-satunya ayah Eun- belikan Ji-seok dari London? Ayah hanya young memberikan kami buku sketsa. Ayah ingat?"

Kim : "Cerita itu lagi. Cerita itu lagi."

Young-

soo

Kim Ji- : “Kakak Ipar!”

seok 
Program Studi Pendidikan Bahasa dan Sastra Indonesia FKIP Universitas Kuningan

$\begin{array}{lll}\begin{array}{l}\text { Jung } \\ \text { Dae- } \\ \text { hyun }\end{array} & : \quad \text { "Ya?" } \\ \text { Kim Ji- } \quad: \quad \begin{array}{l}\text { "Hati-hati dengan Kim Ji-young, dia sangat } \\ \text { keras kepala. Dia memohon kepadaku } \\ \text { selama } 10 \text { tahun demi pena itu." }\end{array} & \end{array}$

Data (03/PAH/00.18.58) yang dicetak tebal di atas merupakan kalimat deklaratif dengan fokus pada frasa verba memohon kepadaku dan nomina pena. Verba tersebut bermakna meminta dengan hormat. Hal ini berarti bahwa Kim Jiyoung meminta dengan hormat pena tersebut selama sepuluh tahun kepada adik laki-lakinya. Ia tidak sekadar memohon pena tersebut, tetapi juga memahami makna pemberian hadiahnya. Melalui data tersebut dapat diketahui bahwa Kim Ji-young berkeinginan untuk menentang pemberian ayahnya yang pilih kasih terhadap ia dan kakak perempuannya dengan adik laki-lakinya

Terdapat pula nilai moral untuk menghargai pemberian orang lain serta patuh dan hormat terhadap orang tua. Selain itu, secara tidak langsung juga terdapat nilai-nilai patriarki yang mensubordinasi pemosisian laki-laki dan perempuan dalam tatanan kehidupan bermasyarakat. Pemosisian tersebut sejalan dengan makna dari pemberian hadiah oleh ayah Kim Ji-young. Adiknya, Kim Ji-seok diberi hadiah berupa pena. Sementara itu, Kim Ji-young dan kakak perempuannya, Kim Eun-young, diberi buku sketsa. Sesuai dengan kaidah moral budaya patriarki bahwa laki-laki dapat secara bebas dan independen menentukan jalan hidupnya sendiri. Sementara perempuan dianggap lebih dependen.

Bentuk mekanisme pertahanan ego yang dimunculkan oleh Kim Ji-young, yakni pengalihan (displacements). Pengalihan merupakan bentuk pertahanan ego ketika tokoh memilih sasaran pengganti dari sasaran sebenarnya yang dapat berupa benda atau orang lain. Alihalih melakukan protes kepada ayahnya yang notabene sebagai pemberi hadiah,
Kim Ji-young memilih secara masif meminta pena tersebut kepada adiknya.

Bentuk pengalihan ini dilakukan atas dasar pertimbangan keinginannya diberi kebebasan menentukan kehidupannya sendiri sebagai perempuan. Keinginan tersebut sekaligus mendobrak kaidah budaya patriarki bahwa perempuan adalah makhluk yang pasif dan dependen. Oleh karena itu, alih-alih melakukan protes meminta pena kepada ayahnya, Kim Jiyoung memintanya kepada adiknya. Sebab ingin menunjukkan bahwa dengan ia memiliki pena tersebut, ia juga mampu menunjukkan eksistensinya sebagai perempuan.

\section{Bentuk Formasi Reaksi (Reaction Formation) \\ Data (04/FMRS/00.08.37)}

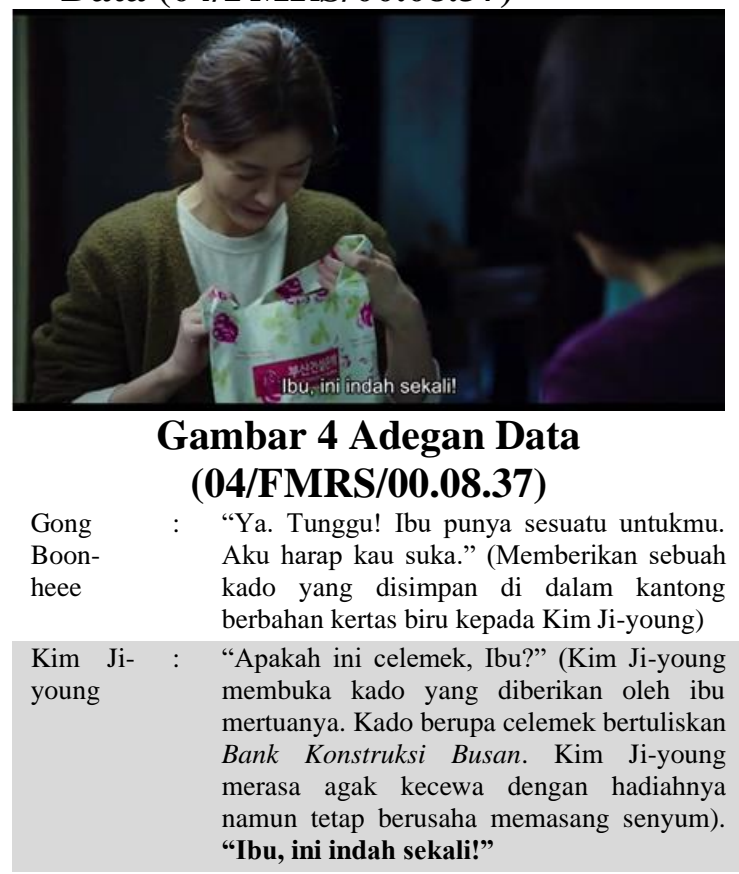

Data (04/FMRS/00.08.37) yang dicetak tebal di atas merupakan kalimat interjeksi yang menyatakan kekaguman. Pernyataan kekaguman tersebut ditandai dengan frasa adjektiva indah sekali. Pada adegan yang ditampilkan, terlihat Kim Jiyoung diberi hadiah celemek oleh ibu mertuanya. Sebelum menuturkan kekaguman atas hadiah celemek yang diberikan ibu mertuanya, Kim Ji-young 
Program Studi Pendidikan Bahasa dan Sastra Indonesia FKIP Universitas Kuningan

memasang wajah datar. Wajah datar tersebut terlihat sekilas saat ia membuka hadiah dan mengenali benda yang menjadi hadiah tersebut. Maka, dapat diketahui bahwa id yang muncul adalah ekspresi wajah datar yang menandakan bahwa Kim Ji-young kurang menyukai hadiah celemek tersebut.

Hadiah berupa celemek tersebut memberikan nilai-nilai tersirat. Nilai tersirat tersebut menggambarkan kaidah sosial masyarakat patriarki. Celemek dikenakan ketika memasak, membersihkan rumah, dan sebagainya. Jika dikaitkan dengan adegan dalam film, maka makna kontekstual dari pemberian hadiah celemek dari ibu mertua Kim Ji-young berisi sebuah pesan. Pesannya yakni agar Kim Ji-young menjadi lebih rajin dan semangat mengerjakan pekerjaan domestiknya sebagai ibu rumah tangga. Perempuan yang diberi hadiah celemek diharapkan agar tetap fokus pada pekerjaannya di dalam rumah, yaitu memasak, mencuci, dan membersihkan rumah. Sesuai dengan khas masyarakat patriarki yang menempatkan perempuan dalam ranah domestik.

Melalui perasaan kurang suka terhadap hadiah celemek dan pertentangan nilai moral agar menghargai pemberian orang lain serta patuh terhadap kaidah moral patriarki, tokoh Kim Ji-young membangun sebuah mekanisme pertahanan ego. Ada pun mekanisme pertahanan yang dibangun adalah bentuk reaksi-formasi. Reaksi formasi dibentuk ketika tokoh mengubah suatu impuls kecemasan yang mengancam dan tidak sesuai serta tidak dapat diterima norma sosial menjadi suatu bentuk yang lebih dapat diterima. Tokoh Kim ji-young awalnya memasang wajah datar saat mengetahui hadiah tersebut berupa celemek, beberapa detik kemudian memasang senyum lalu mengungkapkan kekagumannya terhadap hadiah tersebut.
Mengungkapkan perasaan kurang suka terhadap hadiah juga berkaitan dengan ketidaksepakatannya terhadap nilai patriarki. Hal itu merupakan sikap yang tidak dapat diterima oleh masyarakat. Oleh karena itu, melalui ekspresi senyum dan kalimat interjeksi berupa ungkapan kekaguman menjadi pertimbangan yang dipilih oleh Kim Ji-young untuk ditunjukkan kepada ibu mertuanya.

\section{Bentuk Pembalikan (Reversal) Data (05/PBK/01.44.24)}

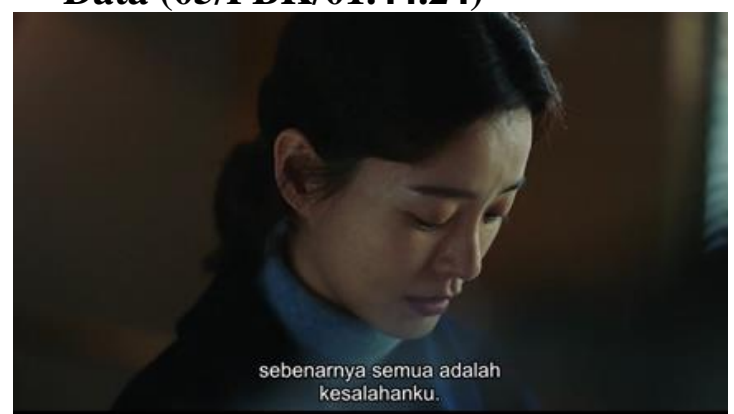

Gambar 4.42 Adegan Data (05/PBK/01.44.24)

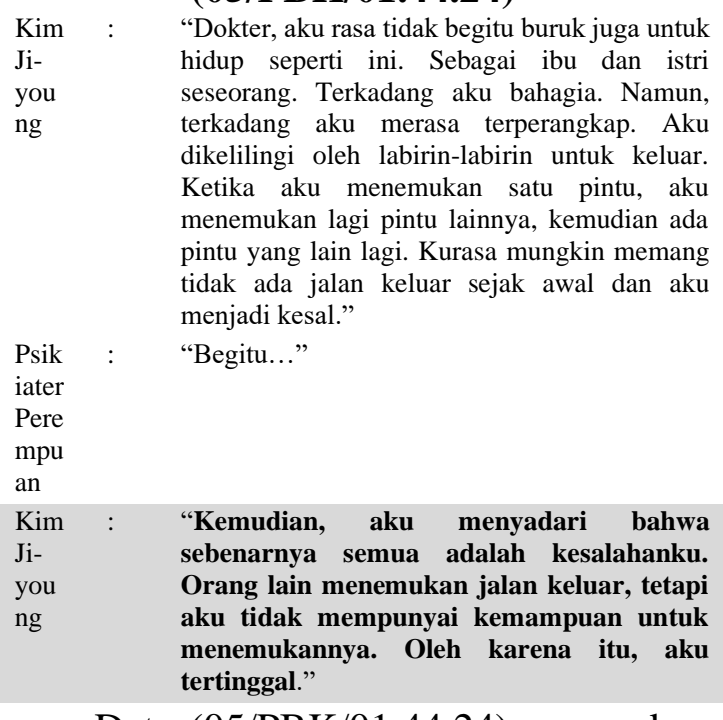

Data (05/PBK/01.44.24) merupakan kalimat deklaratif dengan fokus pada frasa nomina kesalahanku, frasa verba ingkaran tidak mempunyai kemampuan, dan verba tertinggal. Frasa nomina kesalahanku bermakna kekeliruan oleh dirinya sendiri. Frasa verba ingkaran tidak mempunyai kemampuan bermakna sebagai rasa pesimis terhadap kecakapan yang dimilikinya sendiri. Verba tertinggal bermakna ditinggalkan atau berada di 
Program Studi Pendidikan Bahasa dan Sastra Indonesia FKIP Universitas Kuningan

bagian belakang. Oleh karena itu, melalui tuturan tersebut, tokoh Kim Ji-young bertindak pesimis atas ketidakmampuannya menemukan jalan keluar dari kungkungan labirin budaya patriarki yang memenjaranya. Melalui data tersebut dapat diketahui rasa kesal Kim Jiyoung terhadap dirinya yang tidak dapat menyelesaikan masalahnya sendiri.

Penyalahan atas diri sendiri tersebut membentuk mekanisme pertahanan ego yang berupa pembalikan (reversal). Pembalikan (reversal), yakni tindakan mereduksi status ego aktif menjadi pasif dengan mengubah perasaan dan impuls yang menimbulkan kecemasan terhadap orang lain menjadi ke arah sendiri. Alihalih berjuang mencari masalah atas ketidaksepakatannya terhadap ideologiideologi lingkungannya yang patriarkis, tokoh Kim Ji-young menyalahkan dirinya sendiri. Menurutnya, lingkungannya yang patriarkis sama sekali tidak mendukungnya untuk mendapatkan jalan keluar sebagai perempuan yang ingin mengembangkan eksistensi dirinya. Saat ia ingin kembali meniti karier sebagai bagian dari jati dirinya, lingkungannya tidak mendukung sepenuhnya. Oleh karena itu, ia menyalahkan diri karena merasa tidak pernah bisa mencari jalan keluar dari labirin-labirin bernama budaya patriarki.

\section{Bentuk Agresi (Aggression) Data (06/AGR/01.31.28)}

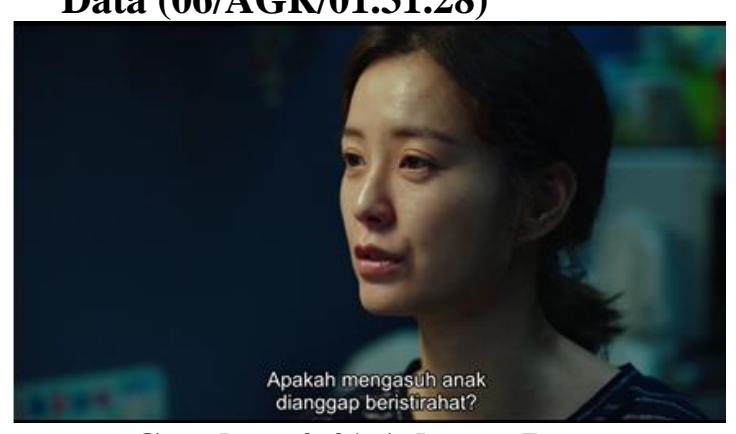

Gambar 4.41 Adegan Data (06/AGR/01.31.28)

Kim : : "Ya, dia menjadi semakin rewel saat waktunya Ji- tidur. Aku akan menemui Kepala Kim dan you memberitahu dia bahwa aku tidak akan bisa ng

\begin{tabular}{|c|c|c|}
\hline $\begin{array}{l}\text { Jung } \\
\text { Dae- } \\
\text { hyu } \\
\text { n }\end{array}$ & & "Mari kita cari jalan terus." \\
\hline $\begin{array}{l}\text { Kim } \\
\text { Ji- } \\
\text { you } \\
\text { ng }\end{array}$ & $:$ & $\begin{array}{l}\text { "Lagipula memang tidak ada, 'kan? Aku sudah } \\
\text { lelah bahkan sebelum kembali bekerja." }\end{array}$ \\
\hline $\begin{array}{l}\text { Jung } \\
\text { Dae- } \\
\text { hyu } \\
\text { n }\end{array}$ & : & $\begin{array}{l}\text { "Baiklah, istirahatlah lebih banyak lagi. Kau } \\
\text { harus beristirahat. Saat Ah-young sudah lebih } \\
\text { besar, keadaan akan lebih baik." }\end{array}$ \\
\hline $\begin{array}{l}\text { Kim } \\
\text { Ji- } \\
\text { you } \\
\text { ng }\end{array}$ & & $\begin{array}{l}\text { "Apakah benar mengasuh anak dianggap } \\
\text { beristirahat?" }\end{array}$ \\
\hline
\end{tabular}

Data (06/AGR/01.31.28) yang dicetak tebal di atas merupakan kalimat interogatif meminta pembenaran dengan fokus pada adjektiva benar. Adjektiva benar bermakna sesuai sebagaimana adanya. Jadi, kalimat pada data di atas mencoba mempertanyakan kembali stereotipisasi yang selama ini dianggap benar bahwa perempuan yang tinggal mengasuh anak di rumah berarti sedang beristirahat. Melalui data tersebut dapat diketahui keinginan Kim Ji-young untuk kembali meniti karier, tetapi tidak mendapatkan dukungan penuh dari suaminya.

Sayangnya, keinginan Kim Ji-young untuk kembali meniti karier bertentangan dengan kaidah moral masyarakat patriarki. Istri tidak boleh menentang pendapat suami, serta anggapan bahwa menjadi ibu rumah tangga dianggap beristirahat dan bukan sebagai pekerjaan. Selain itu, nilainilai masyarakat patriarki bahwa bekerja bagi perempuan hanyalah opsional sebab tugas utamanya adalah tetap di rumah untuk mengurus rumah tangga.

Pertentangan antara keinginan dan kaidah moral masyarakat patriarki melahirkan konflik batin dalam diri Kim Jiyoung. Konflik batin yang berisi kecemasan tersebut pada akhirnya membentuk mekanisme pertahanan ego yang berupa agresi (aggression). Agresi (aggression) merupakan pembalikan pola perilaku secara mundur oleh orang dewasa yang mengalami tekanan psikologis 
Program Studi Pendidikan Bahasa dan Sastra Indonesia FKIP Universitas Kuningan

menuju pola perilaku primitif dan kekanakkanakan. Pola perilaku ini menjurus pada pertengkaran, perusakan atau penyerangan.

Melalui upaya menentang perkataan suaminya, tokoh Kim Ji-young melakukan agresi. Agresi ini dilakukan karena tekanan psikologis yang dialami sebagai ibu rumah tangga dengan berbagai stereotip gender yang menyertainya Selain itu, tindakan agresi ini juga didorong oleh adanya keinginan yang begitu besar untuk kembali meniti karier sementara ia tidak mendapat dukungan penuh dari lingkungannya. Bahkan dari suaminya sendiri.

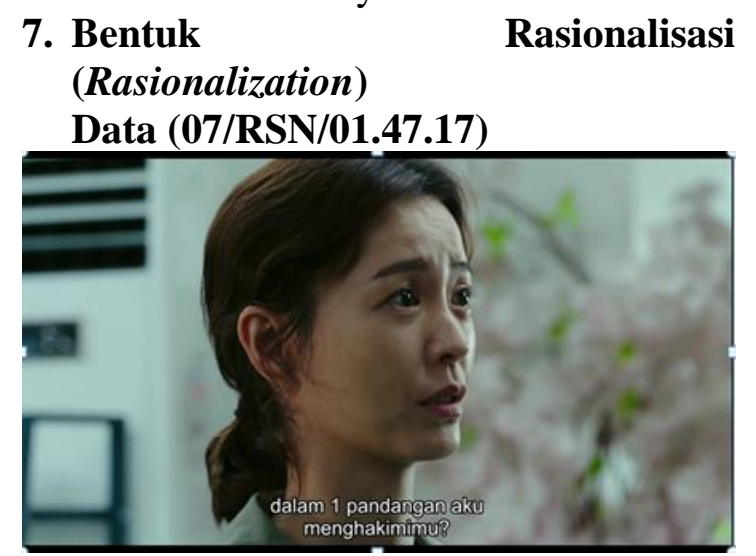

Gambar 4.43 Adegan Data (07/RSN/01.47.17)

Kim : "Mengapa kau menyebutku seperti cacing?"

$\mathrm{Ji}-$

young

Karya : “Ayo kita pergi!” (Mengajak keluar agar wan tidak terjadi keributan, tetapi kedua karyawan Perem laki-laki tersebut menolak.)

puan

Kim

Ji-

young

Karya

wan

Laki-

laki 2

Kim : "Lalu, kepada siapa Anda ingin

Ji- memperdengarkan perbincangan Anda? Aku

young ke sini untuk memesan kopi dan Anda melihatku kurang dari 10 menit yang lalu. Apa yang Anda ketahui tentangku sehingga Anda menghinaku? Apakah Anda tahu apa yang aku lalui, Siapa yang aku kenal dan apa yang aku pikirkan sehingga Anda menghakimiku? Bagaimana jika dalam satu pandangan aku juga menghakimimu?"

Data (07/RSN/01.47.17) merupakan kalimat interogatif dengan fokus pada frasa verba menghakimimu. Verba menghakimi pada kalimat interogatif tersebut bermakna mengadili atau memberikan penilaian. Verba tersebut diikuti oleh kata ganti - mu sebagai kata ganti orang kedua tunggal. Keberadaan verba menghakimi yang diikuti oleh kata ganti -mu yang ditujukan kepada ketiga karyawan tersebut menghasilkan frasa verba menghakimimu. Melalui frasa verba tersebut, Kim Ji-young melakukan sebuah balasan atas perlakuan buruk ketiga karyawan tersebut terhadapnya. Melalui data tersebut dapat diketahui bahwa Kim Ji-young merasa kesal terhadap ketiga karyawan kantoran yang menghinanya secara tidak langsung.

Hinaan yang diterima oleh Kim iiyoung tidak lepas dari adanya nilai-nilai budaya patriarki yang melahirkan stereotip bahwa akses perempuan dan balita terbatas pada ruang domestik. Kekesalan Kim Jiyoung yang awalnya sekadar berupa konflik batin, berubah menjadi bentuk mekanisme pertahanan ego berupa rasionalisasi (rasionalization). Rasionalisasi (rasionalization) adalah mengubah penjelasan negatif ke dalam penjelasan positif sehingga penjelasan atas perilakunya dapat meninggalkan kesan positif dalam masyarakat. Jika ditilik lebih dalam, secara tidak langsung tokoh Kim Jiyoung juga melakukan agresi atau penyerangan balik terhadap karyawan yang menghinanya. Namun, kemudian tindakan agresi ini dirasionalisasi melalui kalimat yang dicetak tebal pada data di atas. Tuturan "Bagaimana jika dalam satu pandangan aku juga menghakimimu?" merasionalisasi tindakannya bahwa yang ia lakukan adalah memberikan balasan yang setimpal dengan ancaman untuk menghakimi balik ketiga karyawan kantoran tersebut.

\section{Bentuk Introjeksi (Introjection) Data (08/ITJ/00.11.37)}


Program Studi Pendidikan Bahasa dan Sastra Indonesia

FKIP Universitas Kuningan

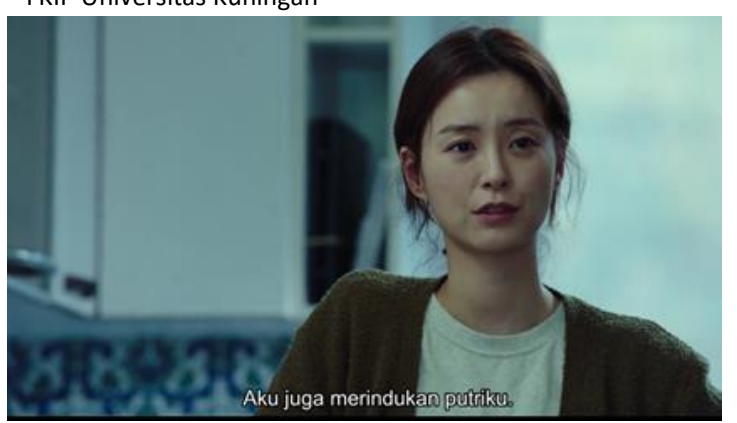

Gambar 8 Adegan Data (08/ITJ/00.11.37)

\begin{tabular}{|c|c|c|}
\hline $\begin{array}{l}\text { Kim } \\
\text { Ji- } \\
\text { young }\end{array}$ & : & $\begin{array}{l}\text { "Baesan, jika kau mau Ji-young beristirahat, } \\
\text { antar dia pulang. Cobalah pikirkan saja, kau } \\
\text { senang melihat putrimu. Aku juga } \\
\text { merindukan putriku." (Berbicara seolah } \\
\text { sebagai ibunya sendiri sambil bertolak } \\
\text { pinggang dengan nada yang sedikit marah). }\end{array}$ \\
\hline $\begin{array}{l}\text { Gong } \\
\text { Boon- } \\
\text { heee }\end{array}$ & : & $\begin{array}{l}\text { "Apa yang dia katakan?” (Bertanya dengan } \\
\text { nada yang heran). }\end{array}$ \\
\hline $\begin{array}{l}\text { Kim } \\
\text { Ji- } \\
\text { young }\end{array}$ & . & $\begin{array}{l}\text { "Putriku seharusnya pergi sebelum putrimu } \\
\text { datang. Mengapa meminta Ji-Young } \\
\text { melayani putrimu juga?" (Masih berbicara } \\
\text { seperti gaya berbicara ibunya dengan nada } \\
\text { yang lebih rendah) }\end{array}$ \\
\hline $\begin{array}{l}\text { Ayah } \\
\text { Jung } \\
\text { Dae- } \\
\text { hyun }\end{array}$ & . & $\begin{array}{l}\text { "Menantuku? Ada masalah apa denganmu?" } \\
\text { (Bertanya dengan nada heran) }\end{array}$ \\
\hline $\begin{array}{l}\text { Kim } \\
\text { Ji- } \\
\text { young }\end{array}$ & ${ }^{\circ}$ & $\begin{array}{l}\text { "Baesan, putriku juga sangat berarti } \\
\text { bagiku." (Berbicara dengan suara bergetar). }\end{array}$ \\
\hline
\end{tabular}

Data (08/ITJ/00.11.37) merupakan kalimat deklaratif berupa penyaranan dengan fokus pada pronomina baesan, putriku, dan putrimu. Pronomina merupakan kata ganti yang menggantikan nomina atau frasa nomina. Ada pun pronomina yang digunakan dalam data di atas, yakni pronomina sapaan baesan dan pronomina kepemilikan putriku dan putrimu. Kim Ji-young merasa lelah dan ingin pulang beristirahat. Kim Ji-young yang sudah sejak kemarin berada di rumah ibu mertuanya membantu menyiapkan banyak makanan untuk perayaan Chuseok.

Terdapat konflik batin antara keinginan dengan nilai moral untuk bersikap dan berbahasa dengan hormat dan patuh kepada orang tua atau orang yang dituakan. Kim Ji-young sebagai menantu harus melaksanakan perintah dari ibu mertuanya. Selain itu, terdapat sebuah nilai-nilai budaya patriarki bahwa seorang menantu perempuan harus mengabdi kepada keluarga suaminya. Utamanya pada hari raya atau hari peringatan keluarga. Perempuan yang notabene sebagai menantu diwajibkan untuk mengabdikan waktunya untuk membantu di bagian dapur.

Bentuk mekanisme pertahanan ego pada data di atas adalah introjeksi. Bentuk mekanisme pertahanan ego ini dilakukan oleh tokoh Kim Ji-young. Melalui introjeksi, Kim Ji-young menggiring adanya kepribadian orang lain ke dalam diri sebagai bentuk penyelesaian masalah batin yang dianggap mengganggu. Adanya nilai-nilai ideal masyarakat untuk bersikap sopan kepada orang tua atau orang yang dituakan menggiring Kim Ji-young untuk mengungkapkan perasaannya sebagai orang lain. Kim Ji-young menggiring kepribadian ibunya, Mi-seok, untuk mengungkapkan keinginannya untuk pulang dari rumah ibu mertunya. Kepribadian tokoh Mi-seok ditandai dengan penggunaan pronomina sapaan baesan yang merujuk pada mertua Kim Jiyoung, dan pronomina kepunyaan putriku yang merujuk kepada Kim Ji-young, serta pronomina kepunyaan putrimu yang merujuk pada saudara ipar perempuan Kim Ji-young.

Ada beberapa alasan pemilihan kepribadian ibunya oleh Kim Ji-young. Pertama, kepribadian ibunya dipilih sebab menurutnya lebih dekat dan memiliki kuasa untuk melakukan pertentangan dengan ibu mertuanya. Kedua, pemilihan kepribadian tokoh Mi-seok ke dalam dirinya juga memberinya sebuah kekuatan. Ditampilkan dalam beberapa adegan bahwa ibunya selama ini menjadi salah satu sistem pendukung dalam upayanya menentang budaya patriarki.

\section{Data (09/ITJ/00.39.13)}


Program Studi Pendidikan Bahasa dan Sastra Indonesia FKIP Universitas Kuningan

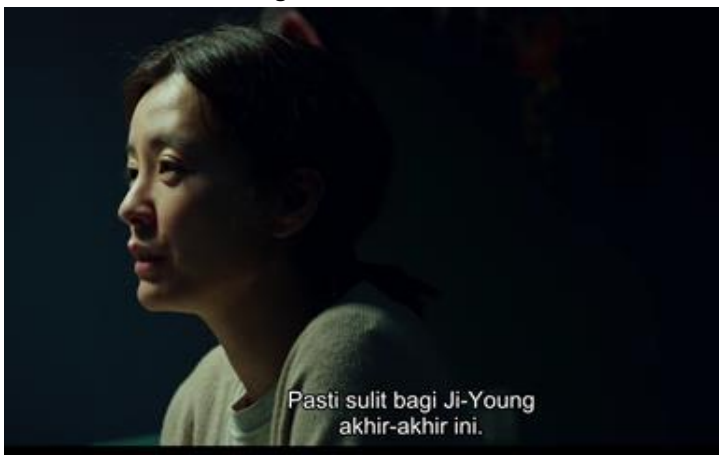

Gambar 9 Adegan Data (09/ITJ/00.39.13)

\begin{tabular}{|c|c|c|}
\hline $\begin{array}{l}\text { Kim } \\
\text { Ji- } \\
\text { young }\end{array}$ & : & $\begin{array}{l}\text { "Hei, Jung Dae-hyun! Pasti sulit bagi Kim Ji- } \\
\text { young akhir-akhir ini. Dia mungkin terlihat } \\
\text { nyaman, tetapi dia khawatir dan tidak sabar. } \\
\text { Tolong katakan kepadanya, 'Kau hebat!', 'Kau } \\
\text { sudah berusaha keras', sering ucapkan 'Terima } \\
\text { kasih!'." }\end{array}$ \\
\hline $\begin{array}{l}\text { Jung } \\
\text { Dae- } \\
\text { hyun }\end{array}$ & : & "Ji-young." (Menatap dengan raut khawatir) \\
\hline $\begin{array}{l}\text { Kim } \\
\text { Ji- } \\
\text { young }\end{array}$ & : & $\begin{array}{l}\text { "Aku tahu kau mencintai istrimu. Tidak usah } \\
\text { menyebut namanya. Semua orang tahu, kau } \\
\text { terlalu kentara!" }\end{array}$ \\
\hline $\begin{array}{l}\text { Jung } \\
\text { Dae- } \\
\text { hyun }\end{array}$ & : & "Ji-young...." \\
\hline $\begin{array}{l}\text { Kim } \\
\text { Ji- } \\
\text { young }\end{array}$ & . & $\begin{array}{l}\text { "Kau masih berpikir aku adalah Cha Seung- } \\
\text { yoon yang berusia } 20 \text { tahun yang } \\
\text { menyukaimu? Bodoh!" (Berdiri meninggalkan } \\
\text { meja makan) }\end{array}$ \\
\hline
\end{tabular}

Data (09/ITJ/00.39.13) yang dicetak tebal di atas merupakan kalimat deklaratif dengan fokus pada pronomina persona $\mathrm{Kim}$ Ji-young dan kalimat interogatif dengan fokus pada pronomina persona Cha Seungyoon. Kedua pronomina di atas merupakan kata ganti yang digunakan untuk menyebut nama orang. Menilik pada data yang dicetak tebal di atas, Kim Ji-young memunculkan bentuk mekanisme pertahanan ego berupa introjeksi. Hal ini ditunjukkan oleh penggunaan pronomina yang menyebut namanya sendiri, Kim $\mathrm{Ji}$ young, sebagai orang lain. Kemunculan introjeksi ini diperkuat oleh munculnya pengakuan dirinya sebagai Cha Seungyoon pada kalimat interogatif yang juga dicetak tebal di atas.

Kim Ji-young merasa sedang berputus asa dan kehilangan semangat saat itu. Keputusannya untuk kembali meniti karier tidak begitu digubris oleh suaminya,
Jung Dae-hyun. Kim Ji-young tidak merasa cukup berani menentang pelarangan suaminya untuk kembali bekerja. Hal itu tidak lepas dari adanya nilai-nilai patriarki yang bahwa keputusan dominan dalam rumah tangga ditentukan oleh suami sebagai kepala keluarga. Oleh karena itu, tokoh Cha Seung-yoon sebagai sahabat Kim Ji-young, sekaligus juga sebagai sahabat Jung Dae-hyun, dimunculkan oleh Kim Ji-young untuk mengeluarkan kegelisahan dan suara hatinya kepada suaminya.

\section{Data (10/ITJ/01.23.17)}

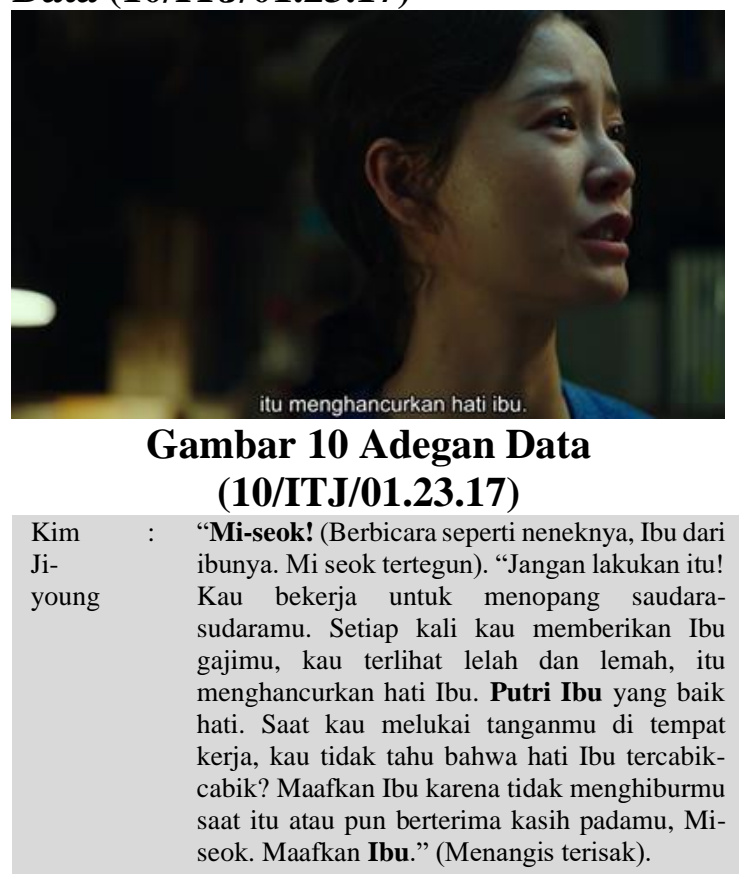

Data (10/ITJ/01.23.17) yang dicetak tebal di atas secara berurutan merupakan kalimat interjeksi panggilan, pronomina kepemilikan, dan pronomina persona. Tuturan Kim Ji-young yang memanggil ibunya dengan interjeksi panggilan $M i$ seok menandakan bahwa ia sedang memunculkan bentuk mekanisme pertahanan ego berupa introjeksi. Ada pun kepribadian yang dimunculkan adalah neneknya, yakni ibu dari ibunya. Hal ini diperkuat dengan pronominal kepemilikan Putri Ibu yang dituturkan, serta pronomina persona $I b u$. 
Program Studi Pendidikan Bahasa dan Sastra Indonesia FKIP Universitas Kuningan

Pemunculan kepribadian atau karakter neneknya ini menandakan bahwa ia sedang merasa gelisah melihat ibunya memasang raut wajah sedih. Selain itu, digambarkan pada beberapa adegan sebelumnya, mimpi ibunya untuk menjadi seorang guru mau tidak mau harus sirna. Hal itu dikarenakan pendidikan lebih diprioritaskan bagi laki-laki pada situasi saat itu. Meskipun notabene, ibu Kim Jiyoung (Mi-seok) terbilang lebih pandai daripada saudara laki-lakinya. Pemuculan bentuk introjeksi ini berkaitan dengan subordinasi atas hak mendapatkan akses yang sama dalam pendidikan bagi laki-laki dan perempuan.

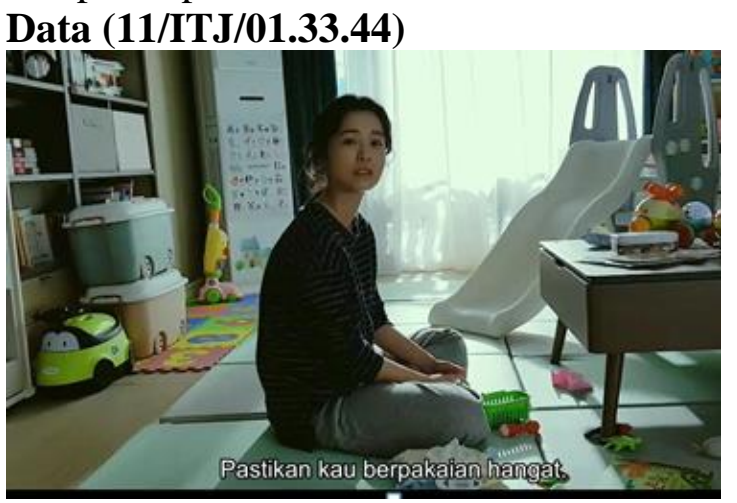

Gambar 11 Adegan Data (11/ITJ/01.33.44)

$\begin{array}{lll}\text { Kim } & : & \text { "Menantuku, hari ini dingin. Anginnya akan } \\ \text { Ji- } & & \begin{array}{l}\text { dingin. Pastikan kau berpakaian dengan } \\ \text { houng }\end{array} \\ \text { hungat." } & : \quad \begin{array}{l}\text { (Tertawa keras) "Sayang, kau terdengar } \\ \text { sangat mirip ibumu." } \\ \text { Dae- } \\ \text { hyun }\end{array} \\ \text { Kim } & : \quad \text { "Ah-young! Kemarilah ke Nenek!" } \\ \text { Ji- } & \\ \text { young } & \end{array}$

Adegan Data (11/ITJ/01.33.44) yang dicetak tebal di atas terdiri atas beberapa kalimat. Pertama, kalimat deklaratif dengan fokus pada pronomina kepemilikan menantuku. Kedua, kalimat deklaratif dengan fokus pada pronomina kepemilikan ibumu. Ketiga, kalimat imperatif dengan fokus pada pronomina persona nenek. Tuturan Kim Ji-young yang memanggil suaminya sebagai menantuku menandakan bahwa ia sedang memunculkan bentuk mekanisme pertahanan ego berupa introjeksi. Bentuk mekanisme ini kemudian diperkuat oleh tuturan Jung Daehyun yang menyatakan bahwa Kim Jiyoung berbicara seperti ibunya. Selain itu, Kim Ji-young juga memanggil putrinya sendiri dengan sebutan nenek.

Saat kalimat percakapan di atas dituturkan, adegan menampilkan latar waktu pagi hari dengan Kim Ji-young sedang duduk bersila dikelilingi oleh mainan anaknya. Tampilan adegan tersebut menandakan sebuah rutinitas pagi Kim Jiyoung sebagai ibu rumah tangga. Ia harus membersihkan mainan anaknya, mengurus suaminya yang akan berangkat bekerja. Hal itu membuatnya merasa kehilangan jati dirinya sebagai seorang perempuan yang dulu sempat meniti karier dengan baik. Sampai akhirnya, ia menikah dan memiliki anak yang harus ia asuh di rumah sendirian.

\section{KESIMPULAN}

Berdasarkan hasil penelitian di atas, bentuk mekanisme pertahanan ego tokoh sentral sebagai pengaruh budaya patriarki dalam film Kim Ji-young, Born 1982 melalui kajian psikoanalisis Sigmund Freud ditemukan bahwa budaya patriarki sangat memengaruhi dimunculkannya mekanisme pertahanan ego oleh suatu individu. Bentuk mekanisme pertahanan ego yang paling sering muncul adalah introjeksi. Hal ini menunjukkan bahwa nilai patriarki mendominasi dan menindas perempuan sebagai pihak inferior. Serta adanya nilai-nilai femininitas yang melahirkan stereotipisasi bahwa perempuan adalah pribadi dengan karakter yang lemah lembut, diam, dan tenang. Oleh karena itu, Kim Ji-young sebagai tokoh sentral dipaksa bungkam. Kim Ji-young merasa tidak berkesempatan untuk mengeluarkan pendapat, gagasan, serta keinginannya sebagai dirinya sendiri.

$$
\text { Introjeksi sebagai bentuk }
$$
pemertahanan ego Kim Ji-young yang menggiring kepribadian ibunya, neneknya, hingga sahabatnya yang dilakukan secara terus-menerus oleh Kim Ji-young menjadi 
Program Studi Pendidikan Bahasa dan Sastra Indonesia FKIP Universitas Kuningan

solusi atas tekanan dan konflik batin akibat pengaruh nilai-nilai budaya patriarki yang terus dilanggengkan. Introjeksi yang terus dimunculkan berulang melahirkan sindrom psikopatologis sehingga Kim Ji-young harus menjalani konseling secara berkala dengan psikiater demi kesehatan mentalnya

\section{DAFTAR PUSTAKA}

Afrikah, A. N., \& Setyorini, R. (2021). Mekanisme Pertahanan dan Konflik Tokoh dalam Novel Si Anak Badai Karya Tere Liye. DEIKSIS, 13(1), 1-11. https://doi.org/10.30998/deiksis.v $13 \mathrm{i} 1.5459$

Boeree, C. G. (2017). General Psychology: Psikologi Kepribadian, Persepsi, Kognisi, Emosi, dan Perilaku. PRISMASHOPIE.

Davison, G. C., Neale, J. M., \& Kring, A. M. (2014). Psikologi Abnormal. RajaGrafindo Persada.

Detik Hot. (2019, November 12). 18 Hari Penayangan, "Kim Ji Young Born in 1982" Raih 3 Juta Penonton [Laman Web Berita]. Detik Hot. https://hot.detik.com/kmovie/d4781252/18-hari-penayangankim-ji-young-born-in-1982-raih3-juta-penonton
Endraswara, S. (2003). Metodologi Penelitian Sastra. Widyatama.

Fakih, M. (2013). Analisis Gender \& Transformasi Sosial. Pustaka Pelajar.

Fatoni, A. S. (2020). Struktur Kepribadian dan Mekanisme Pertahanan Ego Tokoh Utama dalam Naskah Drama Al-Wajhu Al-Muzlimli Al-Qamar Karya Najib Kailani (Telaah Psikoanalisis Sigmund Freud). Aphorisme: Journal of Arabic Language, Literature, and Education, 1(2), 36-57.

Gamlin, J. B. (2020). You See, We Women, We Can't Talk,Wwe Wan't Have an Opinion. Social Science \& Medicine, 252(20), 18.

https://doi.org/10.1016/j.socscim ed.2020.112912

Pieter, H. Z., \& Lubis, N. L. (2016). Pengantar Psikologi untuk Kebidanan. KENCANA.

Setiaji, A. B. (2019). Kajian Psikologi Sastra dalam Cerpen "Perempuan Balian" Karya Sandi Firli. Jurnal Lingue:: Bahasa, Budaya, dan Sastra, 1(1), 21-35.

Yusuf, S. (2004). Pengembangan Kesehatan Mental dalam Kajian Psokologi dan Agama (Pertama). 